\title{
CHEMOTERAPINIU BŪDU GYDOMŲ PACIENTŲ POKYČIAI BURNOJE IR BURNOS PRIEŽIŪROS İPROČIAI
}

\author{
Karolina Ramanauskaitė, Jūratė Zūbienė, Vilija Andruškevičienė, Kristina Saldūnaitė \\ Lietuvos sveikatos moksly universiteto Medicinos akademijos Odontologijos fakultetas
}

Raktažodžiai: chemoterapija, gydymo komplikacijos, burnos pokyčiai, burnos higienos įgūdžiai.

\section{Santrauka}

Tikslas. Ivvertinti pacientų, sergančių onkologinėmis ligomis, pokyčius burnoje ir burnos priežiūros ịpročius chemoterapinio gydymo metu.

Tyrimo metodai. Momentinis tyrimas buvo vykdomas Lietuvos sveikatos mokslų universiteto ligoninès, Kauno onkologijos klinikos dienos chemoterapijos stacionare nuo 2016 metu sausio iki vasario mènesio. Anonimineje anketineje apklausoje dalyvavo 100 onkologinių pacientų, gydomų chemoterapiniu būdu: 62 moterys ir 38 vyrai. Anketoje pateikti dviejų tipu klausimai: apie pokyčius, atsiradusius burnoje chemoterapijos metu, ir apie pacientų burnos priežiūros ipročius gydymo metu.

Rezultatai. Tyrimo rezultatai parode, kad chemoterapinio gydymo metu pokyčius burnoje pajuto net 79,0 proc. tiriamųjų. Dažniausiai pasitaikè burnos sausumas $(52,0$ proc.), sutrikęs skonio pojūtis $(45,0$ proc.), sumažèjo seilètekis ( 36,0 proc.), burnos gleivinès uždegimas (30,0 proc.), dantų jautrumas $(28,0$ proc.), padaugèjo bakterinių apnašų kiekis $(28,0$ proc.), burnos gleivinès kraujavimas (25,0 proc.), nemalonus burnos kvapas ( 23,0 proc.), skausmas burnoje (10,0 proc.), spontaniškas gleivinès kraujavimas ( 8,0 proc.). Nustatyta, kad gydomos moterys kruopščiau prižiūri savo dantis, naudoja ịvairesnes burnos priežiūros priemones bei dažniau lankosi pas gydytoją odontologą.

Išvados. Tyrimo metu nustatyta, kad onkologiniams pacientams chemoterapijos metu pasireiškia gydymo komplikacijos burnoje. Tiriamos moterys kur kas kruopščiau ir dažniau rūpinasi savo burnos priežiūra nei vyrai.

\section{Ivadas}

Onkologinės ligos yra viena aktualiausių visuomenès sveikatos problemų visame pasaulyje bei viena pagrindinių mirties priežasčių šiuolaikinèje visuomenejje [1]. Lietuvoje piktybiniai navikai sudaro beveik 20 proc. visų mirčių ir yra antroje vietoje pagal mirties priežastis po širdies ir kraujagyslių ligų, o sergamumas kaip ir mirtingumas kasmet tolygiai dideja [2]. Pasaulio sveikatos organizacija (PSO) prognozuoja, jog 2040 metais onkologinès ligos bus dažniausia mirties priežastis pasaulyje [3].

Vienas iš efektyviausių ir dažniausiai naudojamų onkologinių ligų gydymo būdų - chemoterapija. Tai gydymas vaistais, kurie naikina vėžines ląsteles arba jų aktyvumą. Pagrindinè vėžinių ląstelių savybẻ yra gebejjimas greitai dalintis ir daugintis, o chemoterapinių vaistų pagrindinis veikimo principas - veikti greitai besidalijančias ląsteles. Todèl šie vaistai gali pažeisti ne tik vėžines, bet ir sveikas, greitai besidalijančias ląsteles [4-7].

Pacientams, kuriems taikomas chemoterapinis gydymas, padideja rizika pašaliniam poveikiui burnoje atsirasti [8]. Burnos pažeidimai chemoterapijos metu priklauso nuo skiriamų chemoterapinių vaistų tipo, jų toksiškumo lygio, gydymo režimo bei dažnio. Taip pat svarbu bendra paciento organizmo būklè prieš ligą ir gydymo metu [1]. Teigiama, kad ne tik chemoterapiniai vaistai, bet ir naviko tipas, paciento amžius, lytis, burnos būkle prieš věžio gydymą ir burnos higienos lygis gydymo metu gali turèti įtakos pokyčiams burnoje $[5,8]$.

Maždaug 40,0 proc. visų chemoterapijos būdu gydomų pacientų pasireiškia ūmios burnos komplikacijos [9]. Dažniausiai pasitaikančios komplikacijos burnoje chemoterapinio gydymo metu yra: burnos gleivinès uždegimas, burnos sausumas, sutrikęs skonio pojūtis, skausmas, bakterinès, virusinès bei grybelinès infekcijos $[1,10,11]$. Vaistai nuo věžio gali sukelti opas burnoje ir gerkleje. Dèl šių vaistų poveikio audiniai gali sausèti, pasidaryti jautrūs, todèl gali prasidèti kraujavimas. Taip pat chemoterapija gali paskatinti dantų èduonies išsivystymą [4]. Labiausiai pažeidžiami minkštieji burnos audiniai, lūpų, ryklès gleivinè, liežuvis, minkštasis gomurys [10]. Šalutinis poveikis gali pasireikšti tiek po pirmo chemoterapinio gydymo ciklo, tiek po kelių mènesių [6]. 
Lietuvoje bei pasaulyje per pastaruosius 5 metus buvo atlikta nedaug tyrimų apie pokyčius burnoje, atsiradusius chemoterapinio gydymo metu.

\section{Tyrimo metodai ir tirtųų kontingentas}

Tyrimas buvo atliktas Lietuvos sveikatos mokslų universiteto ligoninès Kauno onkologijos klinikos dienos chemoterapijos stacionare $2016 \mathrm{~m}$. sausio - vasario mènesi. Anoniminèje anketinèje apklausoje dalyvavo 100 onkologiniu pacientų, gydomų chemoterapijos būdu, apklausos atsako dažnis 100 procentų. Tyrimo metu siekta išsiaiškinti pokyčius pacientų burnoje ir burnos priežiūros ịpročius chemoterapinio gydymo metu. Anketą sudare 15 klausimų: pirmieji - apie pokyčius burnoje, atsiradusius chemoterapinio gydymo metu, antrieji - apie pacientų burnos higienos ịpročius. Atsakymų duomenys suvesti ị SPSS programą, kurios pagalba atlikti statistiniai skaičiavimai. Duomenu patikimumui įvertinti buvo skaičiuojamas statistinis patikimumas $(p<0,05)$ bei hipotezių suderinamumo kriterijus $\chi^{2}$ (chi kvadratas).

Tyrime dalyvavę asmenys buvo atrinkti atsitiktiniu atrankos būdu, remiantis pagrindiniu atrankos kriterijumi visi tiriamieji buvo gydomi chemoterapinio gydymo būdu. Tarp atrinktų pacientų buvo 62 moterys (62,0 proc.) ir 38 vyrai ( 38,0 proc.). Tiriamieji buvo suskirstyti ị tris amžiaus grupes: 27 - 44 metų amžiaus (14,0 proc.), 45 - 62 metų ( 41,0 proc.) ir 63 metų bei vyresni ( 45,0 proc.). Jauniausiam apklausos dalyviui 27 metai, vyriausiajam - 85. Atliktame tyrime didesnę dalị sudarè vyresnio amžiaus pacientai.

Pacientų ligos diagnozavimo vidurkis 26 menesiai, tačiau didžioji dalis pacientų apie savo ligą žinojo vos $2-5$ mènesius ir tik keli tiriamieji onkologine liga sirgo daugiau kaip 5 metus. Tarp tirtų moterų daugiausia dominavo krūties bei kiaušidžių vėžys, tarp vyrų - priešinès liaukos (prostatos) bei plaučių.

\section{Tyrimo rezultatai}

Atlikto tyrimo metu paaiškejjo, kad pokyčius burnoje chemoterapinio gydymo metu pajuto net 79,0 proc. respondentų. Iš jų 55,0 proc. moterys ir 24,0 proc. vyrai (1 pav.)

Burnos sausumą pajuto 52,0 proc. apklausos dalyvių. Šis pokytis reikšmingai dažniau pasireiškẻ moterims nei vyrams. Lyginant tris tiriamujų amžiaus grupes, paaiškèjo, kad burnos sausumas chemoterapinio gydymo metu dažniausiai pasireiškè tarp 63 metų ir vyresnių pacientų ( 25,0 proc.).

Pakitusiu skonio pojūčiu chemoterapijos metu skundèsi beveik pusè (45,0 proc.) respondentų ir šis požymis dažniau pasireiškè moterims. Ryškiausi pokyčiai pastebèti $45-62$ metų amžiaus grupejje $(25,0$ proc.) ir buvo reikšmingai didesni nei tarp $27-44$ metu $-4,0$ proc. $(\chi 2-7,376$, df -2 , $\mathrm{p}<0,025)$.
Atlikto tyrimo metu burnos gleivinès uždegimą pajuto 30,0 proc. tyrime dalyvavusių onkologinių pacientų. Tarp moterų paplitimas buvo statistiškai didesnis nei vyrų. Paaiškejjo, kad šis negalavimas pasireiškè vyresnio amžiaus pacientų grupese: tarp $45-62$ metų (12,0 proc.) bei 63 metu ir vyresnių (13,0 proc.).

Tyrimo rezultatai parodé, kad dantų jautrumą pajuto 28,0 proc. tirtų pacientų, tai reikšmingai dažniau pasireiškè tyrime dalyvavusioms moterims. Gauti reikšmingi skirtumai tarp amžiaus grupių: 18,0 proc. $45-62$ metų, 8,0 proc. -63 metų ir vyresnio amžiaus pacientų grupèse $(\chi 2-8,782, \mathrm{df}-2$, $\mathrm{p}=0,012$ ).

Atliekamo gydymo metu 28,0 proc. respondentų skundèsi padaugejjusiu apnašų kiekiu ant dantų paviršių. Lyginant rezultatus dažniau skundèsi moterys nei vyrai $(25,0$ proc.) bei 45 - 62 metų amžiaus grupès pacientai (16,0 proc.).

Chemoterapinio gydymo metu pacientai dažnai skundžiasi burnos gleivinès ir dantenų kraujavimu. İvertinus nusiskundimus nustatyta, kad burnos gleivinès kraujavimą pastebejjo 25,0 proc. tiriamujų. Nustatyta, kad šis sutrikimas dažniau pasitaiko moterims. Analizuojant amžiaus grupes požymis reikšmingai dažniau pastebètas tarp $45-62$ metų amžiaus pacientu ( $\left(14,0\right.$ proc.) $\left(\chi^{2}-3,176, \mathrm{df}-2, \mathrm{p}=0.204\right)$.

Kita apklausos dalis parode tiriamujų burnos higienos ipročius. Nustatyta, kad beveik visi ( 99,0 proc.) tiriamieji, prižiūrèdami savo dantis, naudoja dantų pastą ir šepetèlị. Respondentai teigè, kad tai yra pagrindinès priemonès kasdienių burnos priežiūros procedūrų metu.

Išanalizavus atlikto tyrimo rezultatus nustatyta, kad vieną kartą per dieną dantis valo 31,0 proc. pacientų, du kartus 51,0 proc., tris - 12,0 proc., ne kiekvieną dieną - 6,0 proc. Vertinant respondentų burnos priežiūros ịpročius, nustatyti reikšmingi skirtumai tarp lyčių. Tyrimo duomenys parodè, kad moterys dažniau arba rečiau nei įprastai dantis valo tik chemoterapijos gydymo metu atsiradus komplikacijoms, bet ịprastai - du kartus. Tuo tarpu vyrai teige, kad dantis dažniausiai ịprastai valo tik kartą per dieną (2 pav.).

Pasiteiravus apie šepetèlio keitimo dažnį nustatyta, kad 20,0 proc. pacientų dantų šepetèli keičia kas du mènesius, 17,0 proc. - kas tris ménesius, 39,0 proc. - rečiau nei kas tris mènesius, o 24,0 proc. - nereguliariai. Nustatyti reikšmingi skirtumai tarp lyčių (3 pav.). Moterys dantų šepetėlị keičia kur kas dažniau nei vyrai.

Atlikto tyrimo rezultatai parodè, kad burnos priežiūrai 44,0 proc. respondentų naudoja burnos skalavimo skysti, 13,0 proc. tarpdančių siūlą bei 5,0 proc. valo liežuvị. Burnos priežiūros priemonių pasirinkimas ir naudojimas yra reikšmingai susijęs su lytimi $(\chi 2-9,158, \mathrm{df}-1, \mathrm{p}=0,002)$. Moterys kruopščiau prižiūri savo dantis, naudodamos įvairesnes burnos priežiūros priemones: 34,0 proc. moterų pa- 
pildomai naudoja burnos skalavimo skysti, 13,0 proc. tarpdančių siūlą ir 5,0 proc. valo ne tik dantis, bet ir liežuvị. Tuo tarpu tik 10,0 proc. vyrų naudoja burnos skalavimo skystį ir jokių kitų papildomų burnos priežiūros priemonių nenaudoja.

Tyrimo metu buvo domètasi ir respondentų lankymosi dažniu pas gydytoją odontologą bei burnos higienistą. Paaiškejjo, kad didžioji dalis apklaustujų (74,0 proc.) pas gydytoją odontologą lankosi tik tada, kai priverčia aplinkybès (skauda, reikalingas gydymas), 18,0 proc. pacientų lankosi vieną kartą per metus, 8,0 proc. - du kartus. Nustatyta, kad moterys dažniau nei vyrai apsilanko pas gydytoją odontologą profilaktiniams patikrinimams $\left(\chi^{2}-10,447, \mathrm{df}-2\right.$, $\mathrm{p}=0.005)$.

Tyrimo rezultatų analizè parodé, kad net 54,0 proc. pacientu $(23,0$ proc. moteru ir 31,0 proc. vyrų) dar niekada gyvenime nebuvo atlikta profesionali burnos higienos procedūra. Tik 26,0 proc. tyrime dalyvavusių pacientų norètų, kad jiems būtu atlikta profesionali burnos higienos procedūra. Iš jų 20,0 proc. moterų ir 6,0 proc. vyrų. Daugiausia profesionalių procedūrų pageidavo tie asmenys, kuriems jau buvo atlikta tokio tipo procedūra daugiau nei vieną kartą gyvenime.

\section{Rezultatų aptarimas}

Mokslinès literatūros analizè ir atliktas tyrimas rodo, kad chemoterapinio gydymo metu pacientai susiduria su pokyčiais burnoje, dažniausiai stebimas burnos gleivinès uždegimas, burnos sausumas, pakitęs skonio pojūtis bei bakterinès, virusinès ar grybelinès infekcijos $[1,10,11]$. Mūsų atliktame tyrime dažniausiai pasitaike burnos sausumas, sutrikęs skonio pojūtis, sumažejo seilètekis, burnos gleivinès uždegimas, dantų jautrumas, burnos gleivinès kraujavimas, nemalonus kvapas, sklindantis is burnos, skausmas burnos ertmèje. Bakterinių, grybelinių ar virusinių infekcijų požymių tarp tiriamų pacientų pastebèta nebuvo. Paaiškejjo, kad net 48,0 proc. pacientų dèl atsiradusių pokyčių burnoje chemoterapinio gydymo metu suprastejo gyvenimo kokybè ir buvo sunkesnè kasdienè veikla.

Atlikus tyrimo rezultatų lyginimą tarp tiriamujų lyčių, nustatyta, kad gydymo metu atsiradę pokyčiai burnoje yra reikšmingai susiję su paciento lytimi ir kur kas dažniau pasireiškia moterims nei vyrams. Furnadzieva M., Slavkov S. ir kt. (2015) teigè, kad su moteriška lytimi yra reikšmingai susijęs burnos gleivinès uždegimas ir jo paplitimas gali būti net iki 83 proc. [6]. Taip pat ir Lopez Ch., Mravak M. atliktuose tyrimuose skelbè, kad chemo-

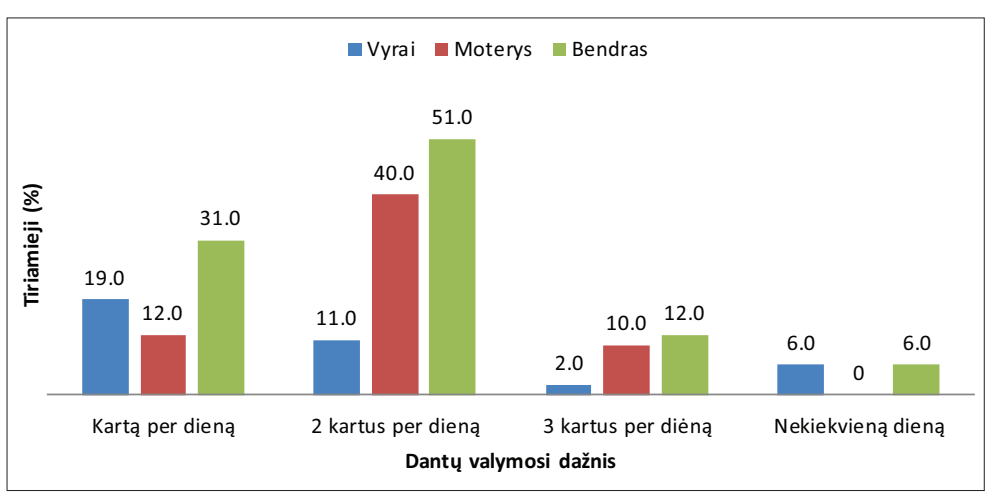

1 pav. Pokyčiai burnoje, atsiradę chemoterapinio gydymo metu, lyginant lytis (burnos sausumas $\chi^{2}-7,771, \mathrm{df}-1, \mathrm{p}=0,005$; burnos gleivinès uždegimas $\chi^{2}$ 8,279 , df $-1, \mathrm{p}=0,004$; dantų jautrumas $\chi^{2}-12,289$, df $-1, \mathrm{p}<0,001$; burnos gleivinès kraujavimas $\left.\chi^{2}-6,848, \mathrm{df}-1, \mathrm{p}=0,009\right)$

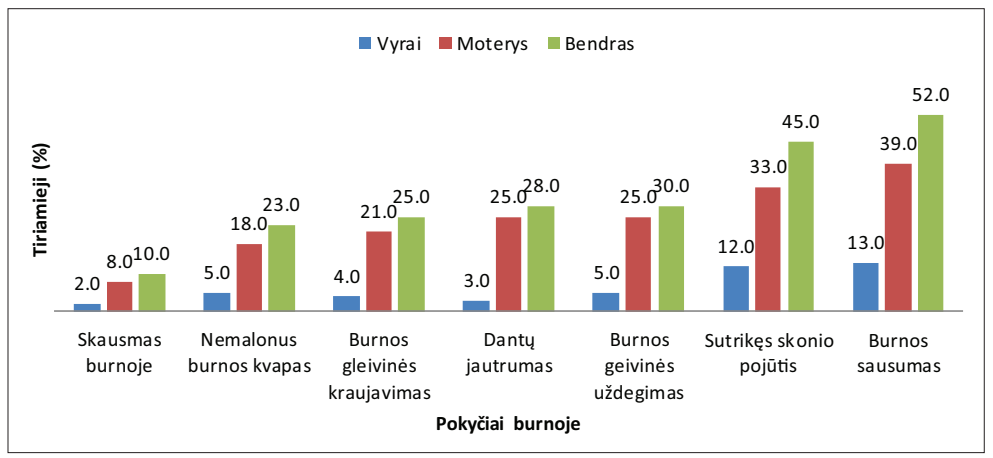

2 pav. Dantų valymosi dažnio pasiskirstymas tarp lyčių $\left(\chi^{2}-25,089\right.$, df -3 , $\mathrm{p}<0,001)$

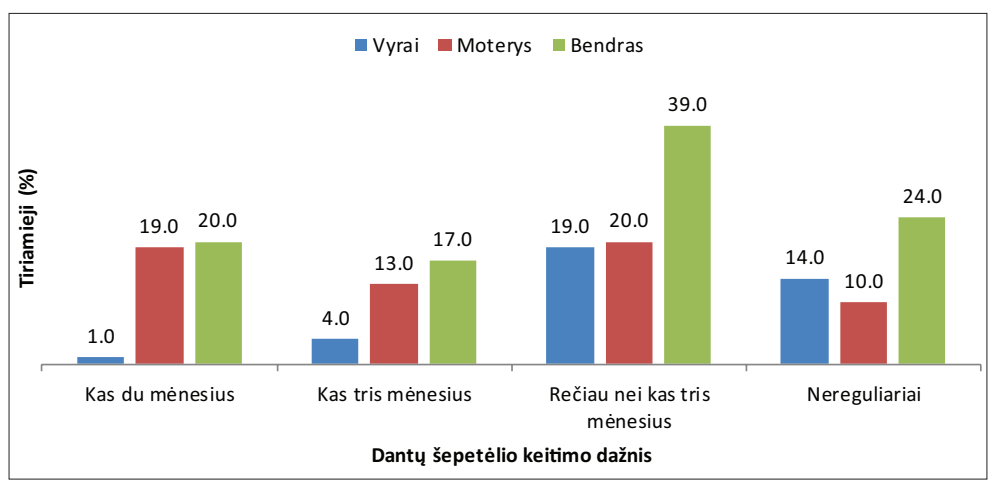

3 pav. Dantų šepetėlio keitimo dažnio pasiskirstymas tarp lyčių $\left(\chi^{2}-16,869\right.$, $\mathrm{df}-3, \mathrm{p}=0.001)$ 
terapinio gydymo metu su atsiradusiu burnos sausumu bei pakitusiu skonio pojūčiu kur kas dažniau susiduria moterys $[10,12,13]$.

Išanalizavus burnos pokyčių pasireiškimą tarp amžiaus grupių nustatyta, kad sutrikęs skonio pojūtis, dantų jautrumas bei spontaniškas burnos gleivinès kraujavimas yra reikšmingai susiję su paciento amžiumi ir kur kas dažniau pasitaiko vyresniems žmonèms $(45-63 \mathrm{~m}$. ir vyresni). Pacientai pakitusị skonio pojūtị apibūdino kaip metalo skonị burnoje arba labai aiškiai juntamą sūrumą, kartumą. Taip pat respondentai teigè, kad skonis yra iš viso dingęs arba jie nesupranta ką valgo. Tiriamieji teigè, kad valgymo metu jusdavo dar ir dantų jautrumą. Skausmo pojūčio burnos ertmëje pasiskirstymas tarp pacientų amžiaus grupių buvo panašus. Ogle O.E. ir Nikoyan L. taip pat nustatè, kad burnos gleivinès uždegimas, burnos sausumas bei sutrikęs skonio pojūtis reikšmingai susiję su vyresniu paciento amžiumi $[14,15]$.

Mūsų atlikto tyrimo metu taip pat buvo analizuojami ir onkologinių pacientų, gydomų chemoterapijos būdu, burnos priežiūros ịpročiai. Nustatyta, kad moterys dantis dažniausiai valosi 2 kartus per dieną, vyrai - vieną kartą. Beveik visi respondentai ( 99,0 proc.), prižiūrèdami savo dantis, naudoja dantų pastą ir šepetėlį. Papildomas burnos priežiūros priemones, tokias kaip burnos skalavimo skystis, tarpdančiu siūlas bei liežuvio valiklis, kur kas dažniau renkasi moterys nei vyrai. Paaiškèjo, kad moterys dažniau renkasi natūralius (druskos, sodos, ramunèlių) savo gamybos skaliklius, o vyrai - pramoninius, taip pat išsiaiškinta, kad vyrai dantų siūlo beveik nenaudoja, bet jei yra būtinybė - renkasi medinius dantų krapštukus. Tyrimo rezultatai rodo, kad trečdalis moterų dantų šepetèli keičia pagal nustatytas rekomendacijas kas $2-3$ mènesius, o vyrai - nereguliariai ir rečiau nei kas 3 mènesius. Rahnama M., Szerwonka B.M. ir kt. (2015) nustatè, kad chemoterapinio gydymo metu, dèl atsiradusio bendro organizmo silpnumo, onkologiniai pacientai kur kas rečiau ir prasčiau rūpinasi savo burnos priežiūra $[5,6]$.

Analizuotoje literatūroje Agarwal A. teigè, kad tinkamas komplikacijų valdymas gydymo metu, padedant ir gydytojui odontologui, bei gera burnos priežiūra ne tik gydymo metu, bet ir prieš jam prasidedant yra labai svarbūs aspektai, didinant paciento gyvenimo kokybę $[12,16]$. Didžioji dalis mūsų apklaustų respondentų pas gydytoją odontologą lankosi tik tada, kai priverčia aplinkybès (skauda, reikalinga pagalba). Profilaktiškai bent kartą per metus pas burnos priežiūros specialistą apsilanko 16,0 proc. moterų ir tik 2,0 proc. vyrų. Idomus faktas, kad net puse tyrime dalyvavusių pacientų nè karto gyvenime nebuvo atlikta profesionali burnos higienos procedūra.

Mūsų tyrimo metu buvo domètasi ir pacientu gyvenimo kokybe. Nustatyta, kad atsiradę pokyčiai burnoje sukèlè ne- malonumų kasdienėje veikloje 48,0 proc. pacientų. Daugiau nemalonumų pajuto moterys nei vyrai. Respondentai teigè, kad atsiradę pokyčiai burnoje kèlè didelị diskomfortą, dèl to sutriko ịprasta mityba, kalbejjimas, burnos priežiūra. Dèl dažno vėmimo pacientai skundèsi atsiradusiomis erozijomis, kurios stiprino atsiradusi dantų jautrumo jausmą.

Burnos bei dantų būkle pacientas turètų pradèti rūpintis dar prieš prasidedant chemoterapiniam gydymui. Ne tik šeimos gydytojas, bet ir gydytojas odontologas bei burnos higienistas turètų tinkamai paaiškinti galimas gydymo komplikacijas bei taisyklingų burnos higienos igūdžių svarbą $[10,17]$.

\section{Išvados}

1. Pokyčiai burnoje (sutrikęs skonio pojūtis, dantu jautrumas, spontaniškas burnos gleivinès kraujavimas, burnos sausumas, burnos gleivinès uždegimas, sumažęjęs seilètekis) yra reikšmingai susiję su paciento amžiumi ir kur kas dažniau pasitaiko vyresniems žmonėms (45-63 m. ir vyresni), taip pat šiuos pokyčius reikšmingai dažniau nurodè moterys nei vyrai.

2. Lyginant tarp lyčių, nustatyta, kad moterys kur kas kruopščiau ir dažniau rūpinasi savo burnos priežiūra bei būkle nei vyrai.

\section{Literatūra}

1. Toscano N, Holtzclaw D, Istvan AH, Shumaker N, Richardson H. Oral implicationsof cancer chemotherapy. The Journal of Implant \& Advanced Clinical Dentistry 2009;1(5):51-67.

2. Deise BV, Zandonade E, Monteiro de Barros Miotto MH. Prevalence of oral manifestations in children and adolescents with cancer submitted to chemotherapy. BMC Oral Health 2016; 16: 107-119.

3. Česas A. Onkologinès ligos ir jų pažangaus gydymo galimybès. Lietuvos gydytojo žurnalas, 2015;2:63-66.

4. Juozaitytė E., Adukauskienė D. Burnos pakitimai sergant onkologinemis ligomis. Onkologija ir hematologija. Kaunas. Vitae Litera, 2014; 93-110.

5. Rahnama M, Madej-Czerwonka B, Jastrzębska-Jamrogiewicz I, Jamrogiewicz R. Analysis of the influence of parenteral cancer chemotherapy on the health condition of oral mucosa. Contemp Oncol (Pozn) 2015;19(1):77-82.

6. Furnadzhieva M, Slavkov S, Markov D, Kolarov R, Krasteva A. Oral cavity changes during and aftercancer therapy. MedInform 2015;24:317-332.

7. Naidu R, Ramana GV, Usha Rani P, Krishna Mohan I, Suman A. Chemotherapy - induced and/or radiation therapy - induced oral mucositis - Complicating the Treatment of Cancer Neoplasia 2004;6(5): 423 - 431.

8. Haun MW, Estel S, Rücker G, Friederich HC, Villalobos M, Thomas M, Hartmann M. Early palliative care for adults with 
advanced cancer. Cochrane Database Syst Rev 2017;12(6):94100.

9. Shahbaz AM, Naveed S, Ahmed A, Abbas Z, Gull I, Amin Athar M. Side effects of chemotherapy in cancer patients and evaluation of patients opinion about starvation based differential chemotherapy. Journal of Cancer Therapy 2014;5: 817-822.

10. López Ch, Gavaldá Esteve C, Sarrión Pérez G. Dental treatment considerations in the chemotherapy patient. J Clin Exp Dent 2011;3(1):31-42.

11. Sonis S, Costa JW. Oral complications of cancer chemotherapy. Holland-Frei Cancer Medicine. 2003; 189.

12. Begonya ChL. Oral toxicity produced by chemotherapy: a systematic review. J Clin Exp Dent 2014;6(1):e81-90.

13. Mravak M. Xerostomia - diagnosis and treatment. Medical Sciences 2012;38:69-91.

14. Su N, Ching V, Grushka M. Taste Disorders: A Review. J can dent assoc 2013;79:d86.

15. Ogle OE, Nikoyan L. Radiation and chemotherapy in oral and maxilo facial surgery. Mohammad Hosein Kalantar Motamedi 2013; 257-274.

16. Agarwal P, Upadhyay R, Agarwal A. Radiotherapy complications and their possible management in the head and neck region. Indian J Dent Res 2012;23:843.

17. Swartzentruber L, Haveles EB. Oral health care during Chemotherapy RDH 2013;67-74.

\section{ORAL CHANGES AND ORAL CAVITY HABITS IN CHEMOTHERAPY PATIENTS}

K. Ramanauskaitė, J. Zūbienė, V. Andruškevičienè, K. Saldūnaitė

Key words: chemotherapy treatment, treatment complications, mouth changes, oral hygiene skills.
Summary

Objectives. The aim of this study was to evaluate the patients, suffering from cancer, oral cavity changes during chemotherapy treatment.

Materials and methods. The survey was taken in Kaunas Clinical Hospital, Chemotherapy day center, starting at 2016 January to 2016 February. 100 cancer patients, 62 women and 38 men, participated in an anonymous questionnaire survey. The questionnaire consisted of two main types of questions: The first - about the changes occurring in the oral cavity during chemotherapy treatment and the second - the patients oral care habits during treatment.

Results. The results showed that even 74 percent subjects on chemotherapy treatment felt changes in the mouth. The most common were: Xerostomia (52,0 percent), Impaired taste $(45,0$ percent), Decreased salivation (36,0 percent), Mucositis (30,0 percent), Tooth sensivity (28,0 percent), Increased plaque (28,0 percent), Oral mucosal bleeding (25,0 percent), Unpleasant odor emanating from the mouth (23,0 percent), Trismus (12,0 percent), Pain in the oral cavity (10,0 percent), Spontaneous bleeding from the mucosa ( 8,0 percent).

Conclusion. The study found that the oncology patients suffers from oral cavity complications caused by chemotherapy treatment. The survey results revealed that women takes care of their oral condition more thoroughly and much more frequently than the men.

Correspondence to: j.zubiene@gmail.com

Gauta 2017-11-30 